\title{
NUMKey: An identification database program for B-forms of Nummulites species (foraminifera; Paleogene) for Windows and Android operating systems
}

\author{
NUMKey: Windows ve Android işletim sistemleri için Nummulites \\ (foraminifera; Paleojen) B-formalarını tanımlamada kullanılan bir \\ veritabanı programı
}

\author{
Ali DEVECILER ${ }^{1}$ (iD), Sinan AKISKA \\ 1,2Department of Geological Engineering, Faculty of Engineering, Ankara University, Ankara, Turkey. \\ adeveci@eng.ankara.edu.tr, akiska@eng.ankara.edu.tr
}

\section{Öz}

Nummulites is an index taxon for the Paleogene period. Because of the numerous species of this genus, it takes some time to identify and describe the species. Thus, NUMKey has been developed as a tool to provide convenience for paleontologist in definition of Nummulites species. This program has been written for a Windows operating systems with Visual Basic and an Android mobile systems with Java (Eclipse) to determine microspheric specimens of 138 Nummulites species. Important physical characteristics for identifying the speciessuch as granulation, shape of test, septal filaments, shape of septa at adult stage, $H$-L ratio of a chamber and central knob-have been entered into the database. Since the program includes an open-source code, this aspect permits the modifications both on the source code and the database.

Key Words: Foraminifera, Nummulites, Database, Paleogene, identification key

\section{Introduction}

Genus: Nummulites [1] is considered as an index taxon to determine the exact age of the lithostratigraphic units from late Thanetian to early Oligocene of the Paleogene period. As a rotalid, it has always been an interesting fossil for the paleontologists, and various scientific studies have been made about this genus since the first paleontological explorations. Despite the fact that this taxon was first announced as Camerina laevigata by [2], Nummulites [1] was accepted as a valid name for its frequent use in many scientific literatures. Also, many other names like Nummulina, Nummulitella, Nummularia, Nummulita have been used as synonyms [3]. This dominant taxon of the Eocene shallow-water strata can show morphological changes due to environmental conditions [4]-[5] causing numerous types of Nummulites species and biostratigraphic diversity in the Paleogene period. Because of that, taxonomy might be very complicated, several morphological observations are due, and many biometric parameters have to be measured. NUMKey has been prepared to provide support in the determination process of Nummulites species for the paleontologists.

The NUMKey is both compatible with the Android and Windows operating systems, which contain main features of the microspheric forms of Nummulites species. In this study, 120 species around the Alpine-Himalayan zone in [6], which
Abstract

Nummulites Palojen devri için karakteristik bir taksondur. Birçok tür barındıran bu cins için tür tanımı yapmak oldukça zaman almaktadır. Bu yüzden, NUMKey bu cinsin türlerinin tanımlarında paleontologlara kolaylık sağlayan bir araç olarak geliștirilmiștir. Bu program, 138 Nummulites türünün mikrosferik bireylerinin tanımlanması için Visual Basic ile Windows ișletim sistemi, Java (Eclipse) ile Android mobil işletim sistemi için yazılmıştır. Türlerin tanımlanması için önemli olan; granül, kavkı șekli, bölme izleri, ergin evredeki bölme şekli, locanın H-L oranı ve merkezi düğme gibi fiziksel özellikler veri tabanına girilmiștir. Programın açık kaynak kodlu olması, hem veri tabanında hem de kaynak kodunda değişiklikler yapmaya izin vermektedir.

Anahtar Kelimeler: Foraminifera, Nummulites, Veri tabanı, Paleojen, Tanımlama anahtarı

has been much cited for its contribution to the larger foraminiferal biostratigraphy of the Tethyan Paleocene and Eocene, have been considered (Figure 1). In addition, 18 species from [7], characteristics of the common taxa, have been taken from [3],[7]-[13]. They are followed by many researchers for their reliability on the systematic paleontology of Nummulites genus. The characteristic aspects of Nummulites species used in this program are beading (granulation), shape of test, septal filaments, shape of septa at adult stage, H-L ratio, and central knob. After query the database for the presence of this specific feature, multiple species with these similar characteristics can be detected. In such cases, the user must determine the exact species with the help of the main relevant literature due to similarities in key features of some species.

Several online taxon-based paleontological databases are available, such as Fossilworks (http://fossilworks.org/), Global Biodiversity Information Facility (http://www.gbif.org/), North Carolina Museum of Natural Sciences Online Collections (http://collections.naturalsciences.org/), World Register of Marine Species (http://www.marinespecies.org/), Catalogue of Life (http://www.catalogueoflife.org/), and Paleobiology Database (https://paleobiodb.org/). Even if these databases contain the large numbers of species, all of them are cataloguetype databases that have the name of species, location, sampling date, environment, etc. None of them have compare tools or the physical features of the species. 
Taxonomy-based software, both commercial and noncommercial, is also available ([14] and references therein). However, a database program comparing the differences amongst the physical properties of the Nummulites species is not available.

The main aim of this program is to detect the B-forms (microspheric generation) of Nummulites species based on some important physical characteristics by scanning through the program's database. Although A-forms (macrospheric generations) are abundant in thin sections, B-forms show more characteristic structural elements to observe and they are distinctive in size and easy to recognize in the field.

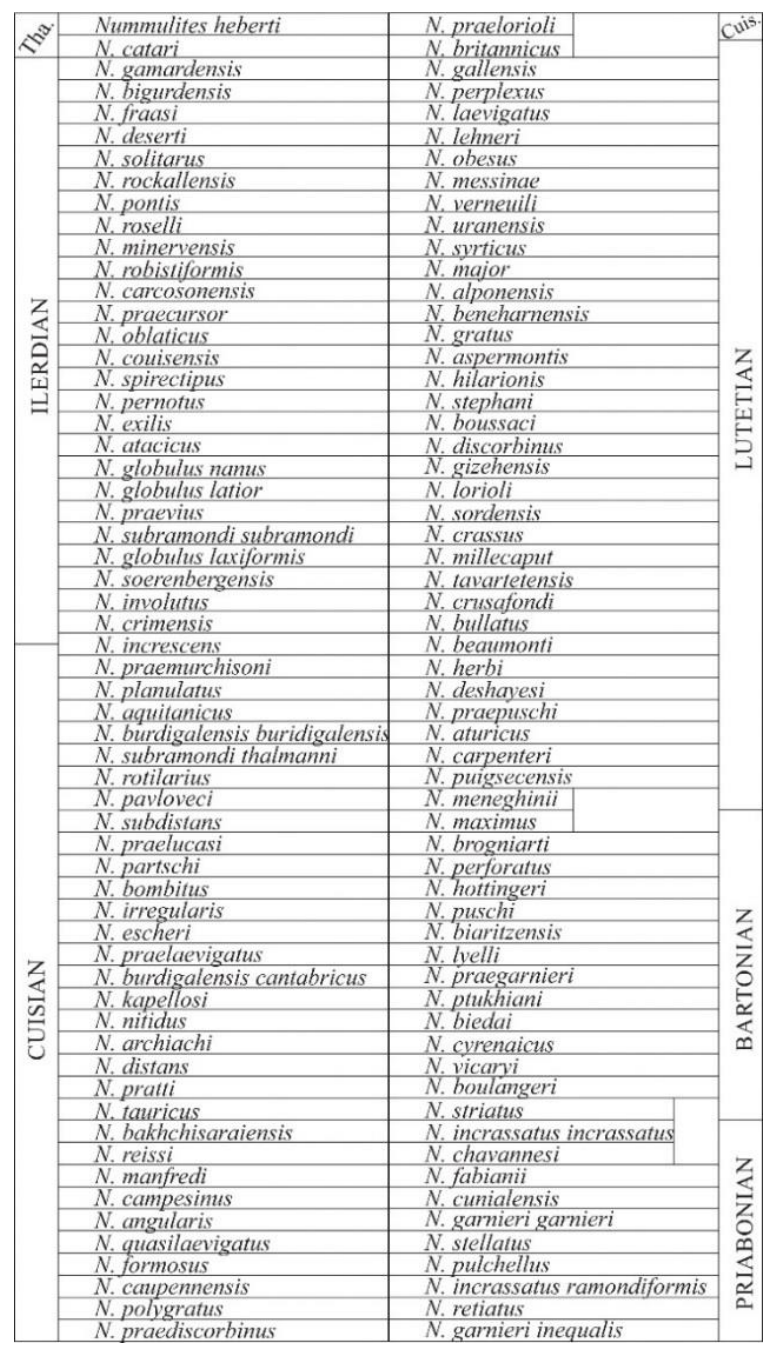

Figure 1: Shallow bentic zones (SBZ) and stratigraphic distribution of the species of Nummulites in the Tethys area [6].

\section{The morphology of Nummulites}

The Nummulites (Figure 2) is a larger shallow-water benthic foraminifera with a planispiral, involute coiling and hyaline calcerous wall. This genus is common in Paleogene lithostratigraphic units, and is useful for determining age only in tropical and subtropical environments of shallow water strata. The morphology of this genus could be analyzed in two parts, including external and internal morphology. We used works by [7],[13],[15]-[17] as the key literatures to determine the basic features.

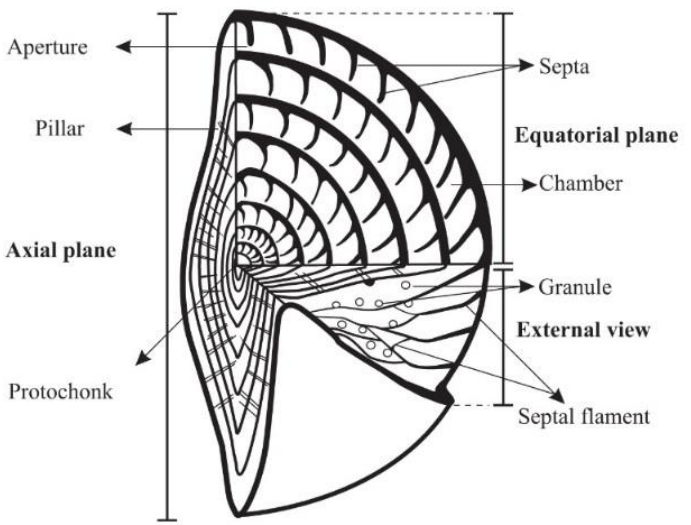

Figure 2: The general view of the structural elements of the Nummulites on the outer surface and in the axial-equatorial sections (modified from [13]).

\section{$2.1 \quad$ The external morphology}

The external morphology includes the features that can be observed on the surface of Nummulites species. These features are test shape, beading, septal filaments and umbo. To explain these features:

Test shape: It varies between thin lenticular and inflated lenticular (Figure 3).

Beading (Granulation): A bead is a small, rounded or hemispherical protuberance on the surface of lamellar shells forming a pillar over septa [17], (Figure 2). Generally, the presence or absence of this property is used for the first distinction of the species.

Septal filaments: A septal filament is a track of a septum on the surface of the test, and Nummulites species have their own characteristic shapes of septal filamnets. There are four types of septal filaments: 1) radial, 2) sinusoidal, 3) meandriform, 4) reticulated (net shaped) [7], [13] (Figure 4).

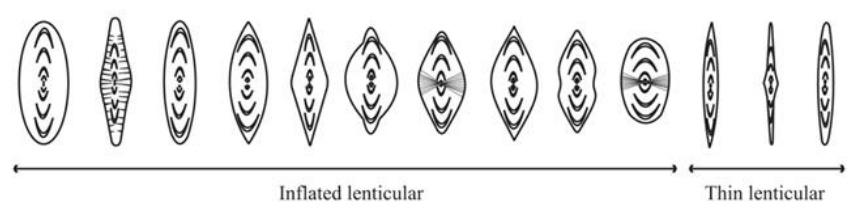

Figure 3. The variety on the test shape of the Nummulites species (modified from [13], [18]).

Umbo (Central Knob): The umbo is a round and large pustule on the center of the test and an essential property for some species. This important structural component can be clearly observed in the axial thin sections [17].

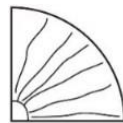

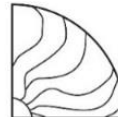

2

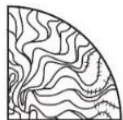

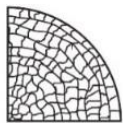

Figure 4: The septal filaments on the surface of the Nummulites species. 1: Radial, 2: Sinusoidal, 3: Neandriform, 4: Reticulated (net shaped) (modified from [7],[13]).

\subsection{The internal morphology}

The internal morphology can be seen in the equatorial and axial sections of the specimens, and these are very significant for the accurate identification of the species. The basic inner features- 
such as proloculus, chambers, septa, and the character of the coiling-can be observed in equatorial-oriented sections.

Proloculus: The first spherical chamber of a foraminiferal test is called proloculus [17]. The size of proloculus can show varieties because of dimorphism or trimorphism. The proloculus of Bforms is not considered due to small size.

Chamber: The test cavity and its surrounding wall, formed at one instar in a multilocular species, is called the chamber [16]. The height-length (H-L) ratio represents the inner measurement of a chamber. This ratio is divided into three groups such as; $\mathrm{H}<\mathrm{L}, \mathrm{H}=\mathrm{L}$ and $\mathrm{H}>\mathrm{L}$.

Septa: Partitions between chambers are called septa [16]. The shape of the septa can differ according to the species [13] (Figure 5).
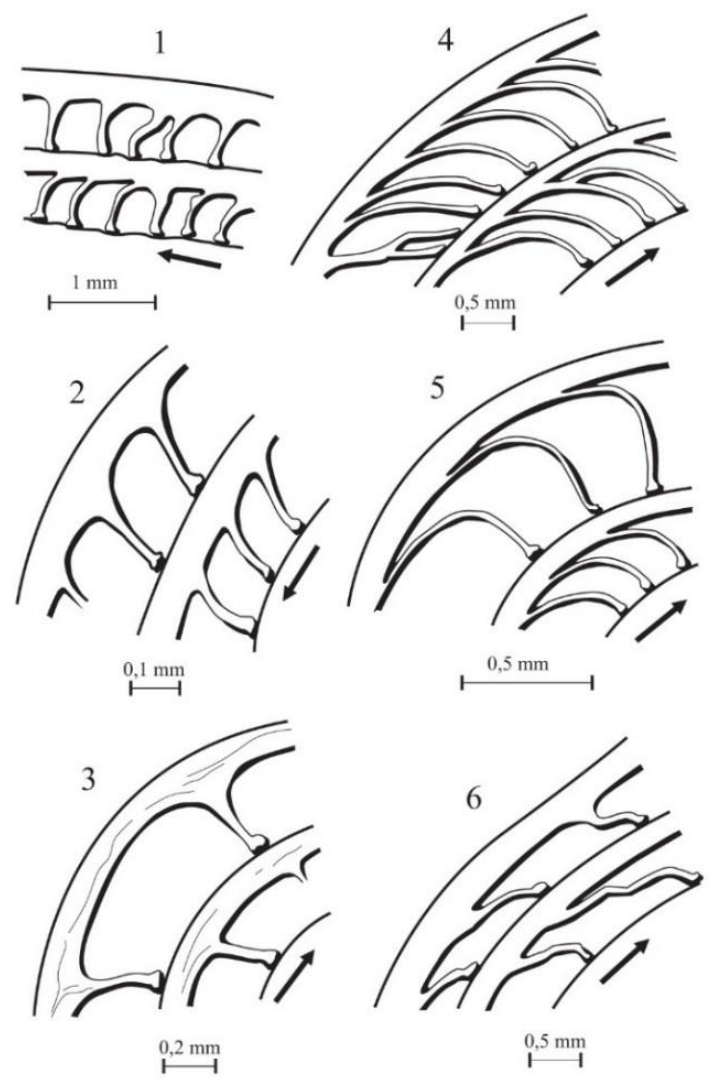

Figure 5: The shape of septa at adult stages of the Nummulites species. 1: Close aligned, slightly inclined (e.g. N. gizehensis),

2: Close aligned, slightly arch shaped (e.g. N. variolarius),

3: Spaced, slightly inclined-straight (e.g. N. intermedius),

4: Dense aligned, falcate (e.g. N. distans), 5: Slightly dense aligned, straight, falcate (e.g. N. concinnus), 6: Spaced, flexuous (e.g. N. aturicus) (modified from [13]).

Coiling: Coiling defines the regularity and tightness in the whorl sequence. For some species, this can be a distinctive property [17]. For example, $N$. irregularis has a typical irregular coiling, and $N$. perforatus has tripartition coiling, which consists of tight coiling at the beginning (the juvenile stage), a laxer part (the adult stage), and tight coiling again at the end (the gerontic stage).

\section{System requirements and prerequisites}

NUMKey is user-friendly, free and independent of all other applications (e.g. some macros in MS Excel). It also uses open source code, so modifications can be made to the software. The program and the source code can be downloaded from "http://80.251.40.59/eng.ankara.edu.tr/akiska/numkey/", a site hosted by Ankara University, Turkey.

In order to run the application for Windows operating systems, Microsoft .NET Framework 2.0 or following version must be installed. If not, the installer will request the installation of .NET Framework during the program installation. If the program fails to install after .NET Framework installing, the user may need to install the service packs of .NET Framework. After installation, the shortcut to the program can be seen on the desktop and in the startup menu.

The most reported error is the connection of the database if the user runs MS Office 2003 or previous versions (or does not use MS Office). "The 2007 Office System Driver: Data Connectivity Components" program should be installed on the computer when given this type of warning. This software can be downloaded from the Microsoft website [19].

For Android Mobile Operating Systems, there is no need for any requisition for the pre-installation. The minimum Android system version should be 2.3.3 (Gingerbread). Even if we did not test the program on the Android 2.2 system version (Froyo), it is still possible to work in this version. The system features needed to run the NUMKey program for both operating systems are shown in Table 1.

Table 1: System properties of the NUMKey program.

\begin{tabular}{ccc}
\hline Operating System & Windows XP, Vista, 7, 8 & $\begin{array}{c}\text { Android 2.3.3 } \\
\text { or newer }\end{array}$ \\
\hline Framework & .NET Framework 3.5 & - \\
Database & Access 2007 & SQLite 3.8.9 \\
Screen Compatibility & 1024x768 pixels & No restrictions \\
& (minimum) & \\
\hline
\end{tabular}

\section{Program details}

The software is created for easy identification of Nummulites species. It was written in Visual Basic .NET 3.0 for Windows operating systems and Java (Eclipse) for Android Mobile operating systems and compiled in these programs.

For Windows operating systems, the features of the species were entered into the Access 2007 database program with the main features of "age", "granulation", "shape of test", "septal filaments", "shape of septa at adult stage", "H-L ratio", and "granulation (umbo)". The user can modify the database (numm_db.accdb) in the Access 2007 (or later) database program. The database file can be found in the installation folder of the program.

The main window of the program is divided into three sections. The "Search" text box and the features to be selected for query are located in the upper left of the window, while the figures for septal filament and the shape of septa at adult stage are seen in the upper right (Figure 6a). The figures are connected to the "septal filament" and "shape of septa at the adult stage" comboboxes. By selecting these features on the comboboxes, these figures will change to the related figures (Figure 6b). The species of the Nummulites with their characteristic aspects, connected to the database table are located in a scrolling list at the bottom of the window. The "Search" field is connected to the "Name of the species" column in the database. After typing each letter into the "Search" field, the database queries automatically and the results are shown (Figure $6 \mathrm{c}$ ). The user can double-click on an exact species in the database table to see all the features of the selected species (Figure 6d). 


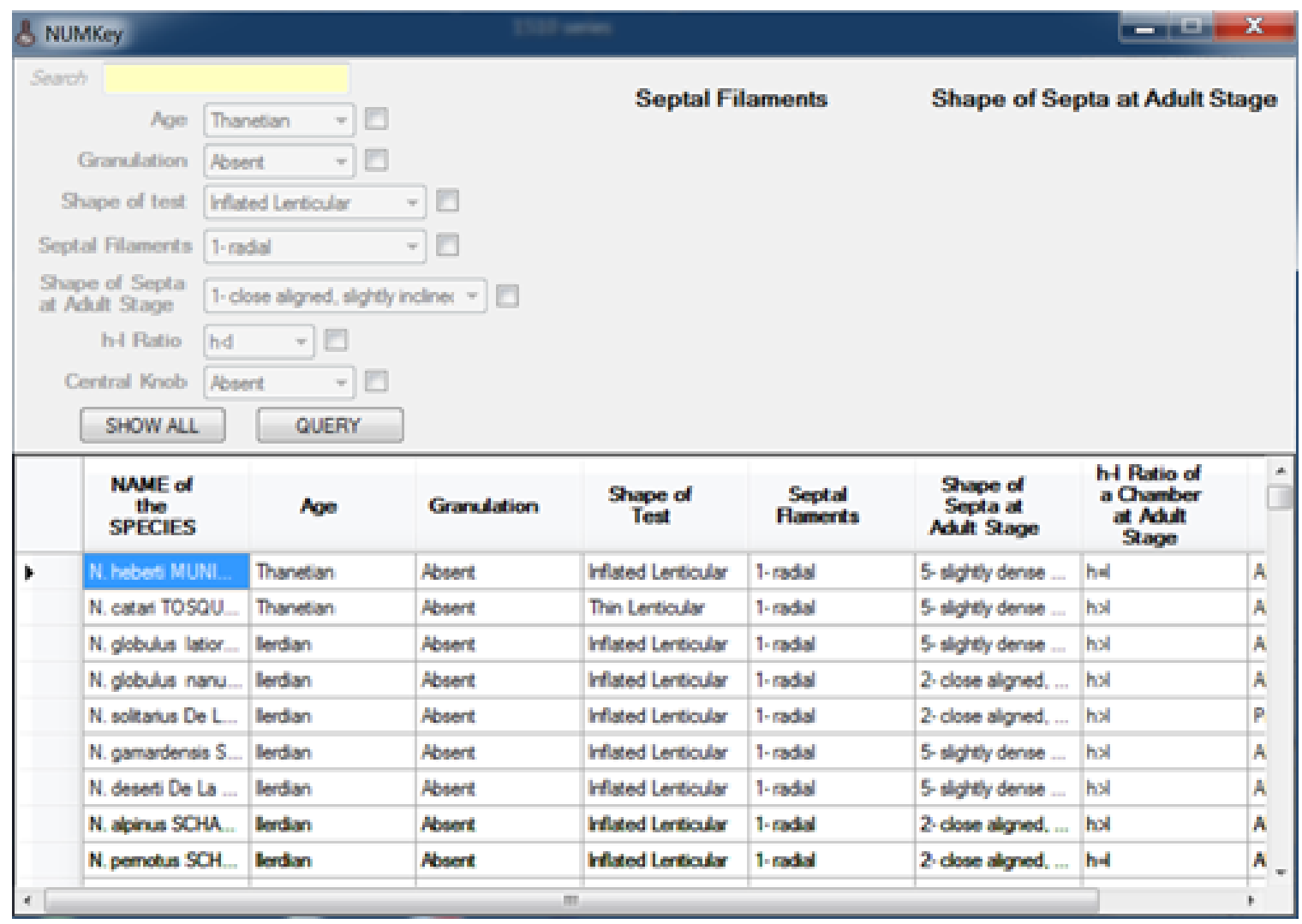

(a)

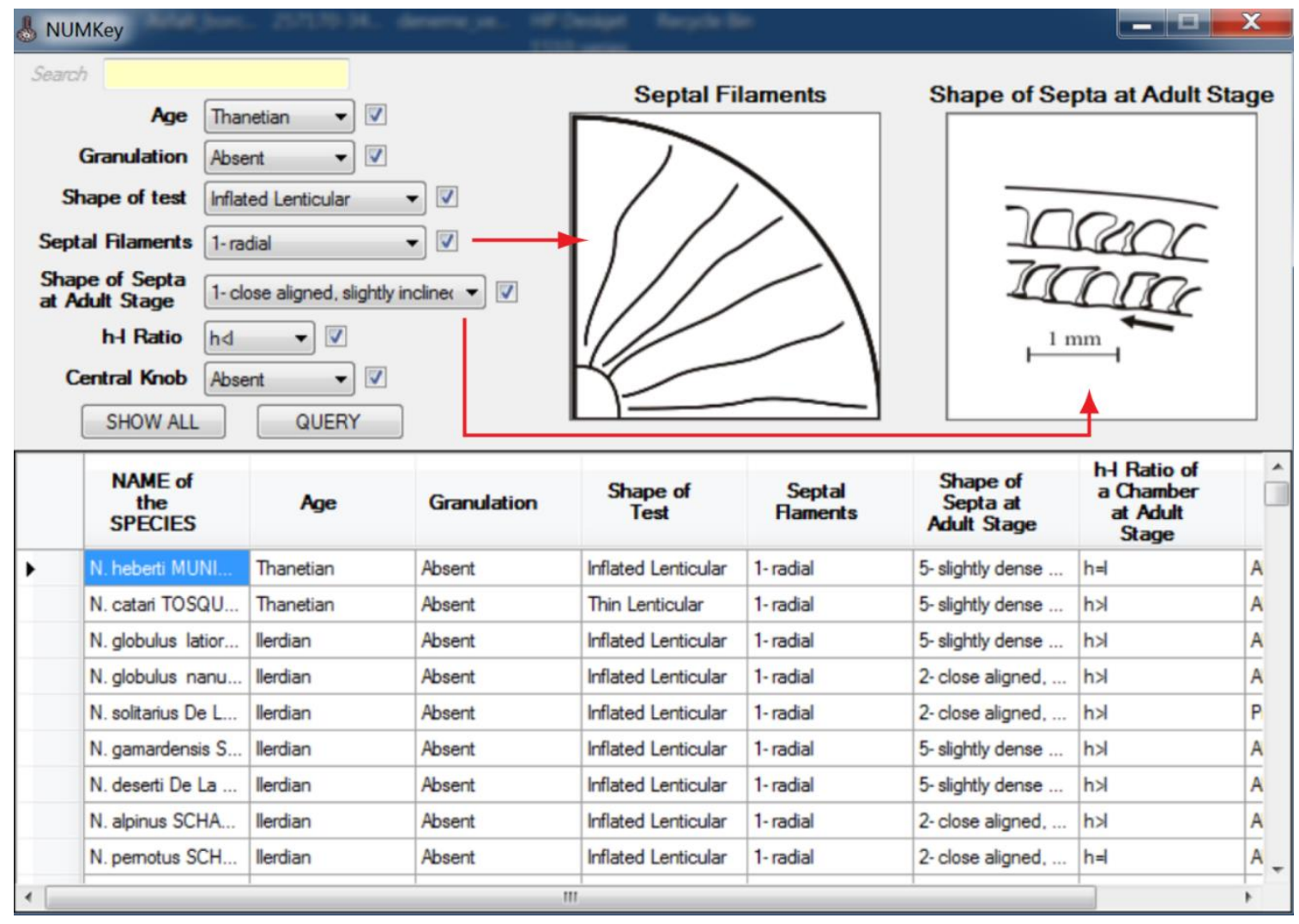

(b)

Figure 6: (a): General view of the program, (b): Selecting "Septal filaments" and "Shape of Septa at Adult Stage" properties, which are connected to the pictures on the right of the screen. 


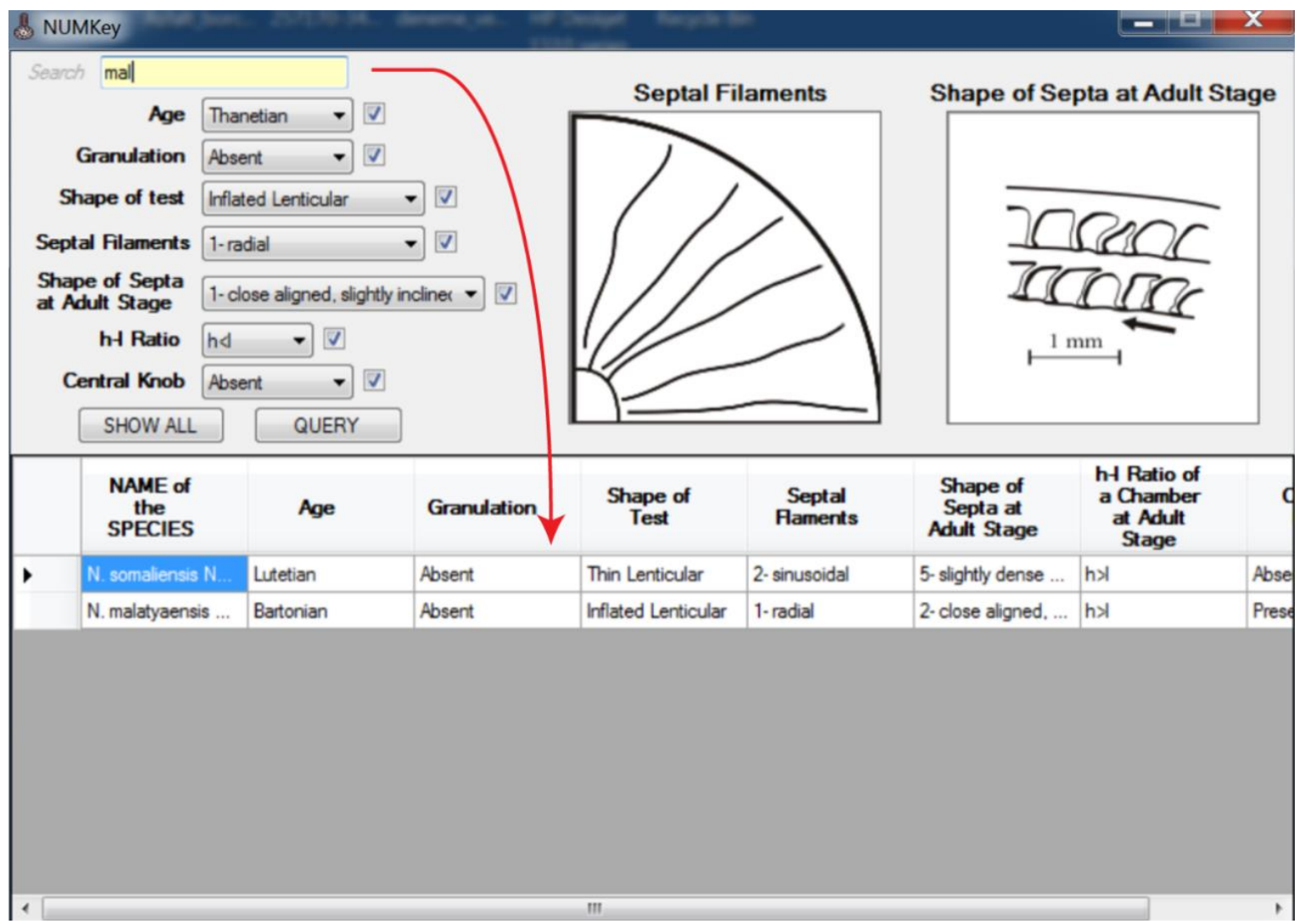

(c)

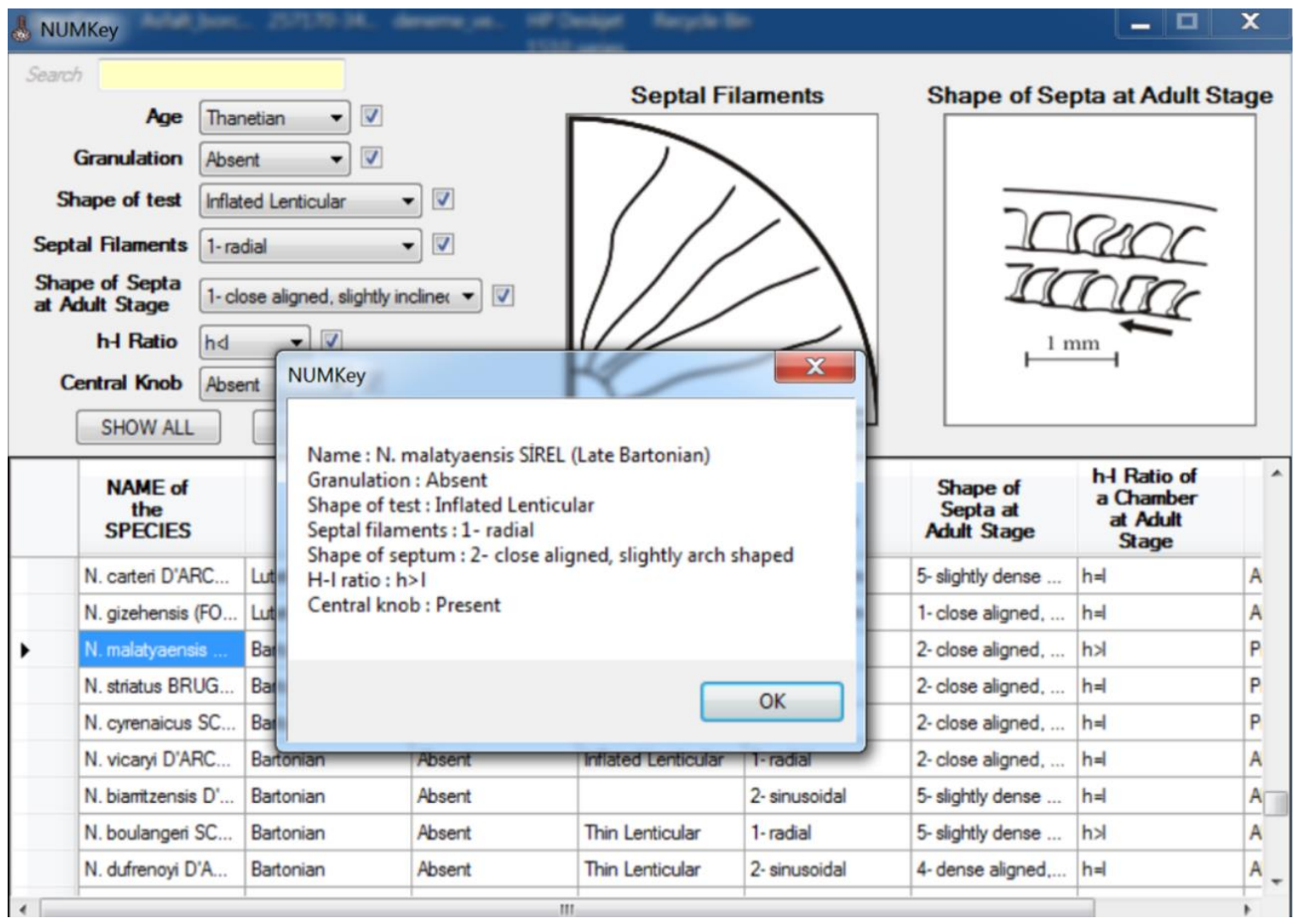

(d)

Figure 6: (c): The view of the database table when typing the letters in the "Search" textbox, (d): The view of all features of the selected Nummulites species when double-clicked. 
For Android mobile operating systems, the features of the species were entered into the SQLite database program with the same way as in the Windows operating systems. The database file (veritabani-v1.db) can be found in the program's installation folder. The screen view of the program is quite similar to that of Windows operating systems. While the comboboxes (spinners in Android) and the checkboxes leading to the features of the species are seen in the upper part of the screen, the "Search" and the "Add data" icons are located on the action bar (application bar). The database table is located at the bottom of the screen (Figure 7a). The user can get detailed information about the species by pressing on and also editing the features of the species in the detailed information screen (Edit Data screen) (Figure 7b). The figures of the "septal filament" and the "shape of septa at the adult stage" are not located in this screen due to lacking of space. These figures can be accessed by clicking the "Settings" button on the action bar (Figure 7c). After clicking on these properties, a new window will be opened and the picture of the related property will be shown.

The "Search" field is connected to the "Name of the species" column. After typing a few letters into the "Search" field, the

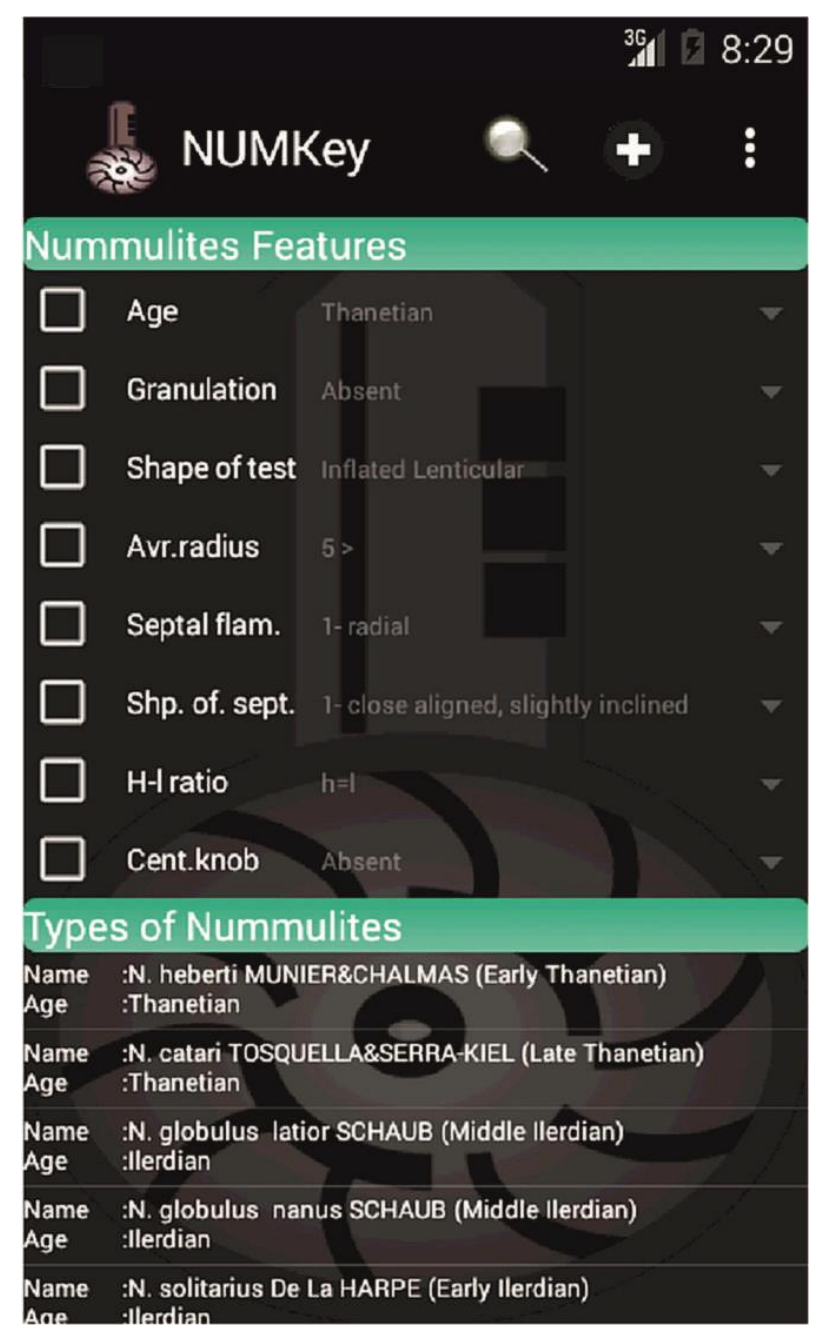

(a) database makes the query automatically and the results are shown (Figure 7d). This section can be used to view and edit the properties of an individual species.

The comboboxes on the main screen correspond to searchable properties of the database. The user can choose the properties in the comboboxes to find species of Nummulites that match the selected properties. The program makes a query considering all of the properties selected and shows the results on the database table. If some aspects of the species are not determined (or uncertain), the user can uncheck the checkbox at the left of the combobox related to the undetermined property. These unchecked properties are not considered when querying the database. Some physical properties of Nummulites species (such as "H-L Ratio" feature of N.hottingeri SCHAUB) has not been added into the database because these properties are not specified in the related literatures. However, these species are shown according to whichever feature is chosen in the query. Users can add these features into the database via Microsoft Access software (2007 or following version) for Windows operating system and via SQLite Database Browser program (Free License) for Android operating system.

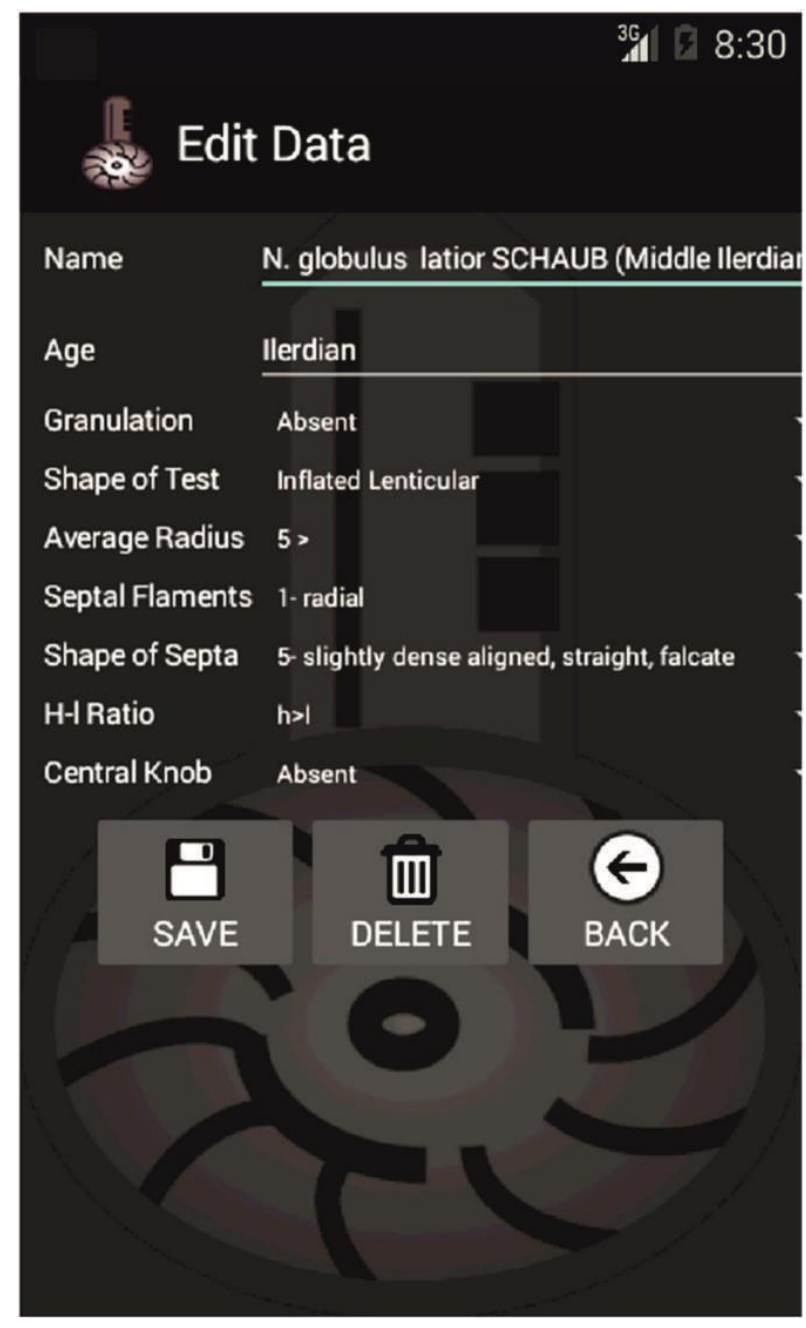

(b)

Figure 7: (a): General view of the program on an android device, (b): "Edit Data" screen on the program. 


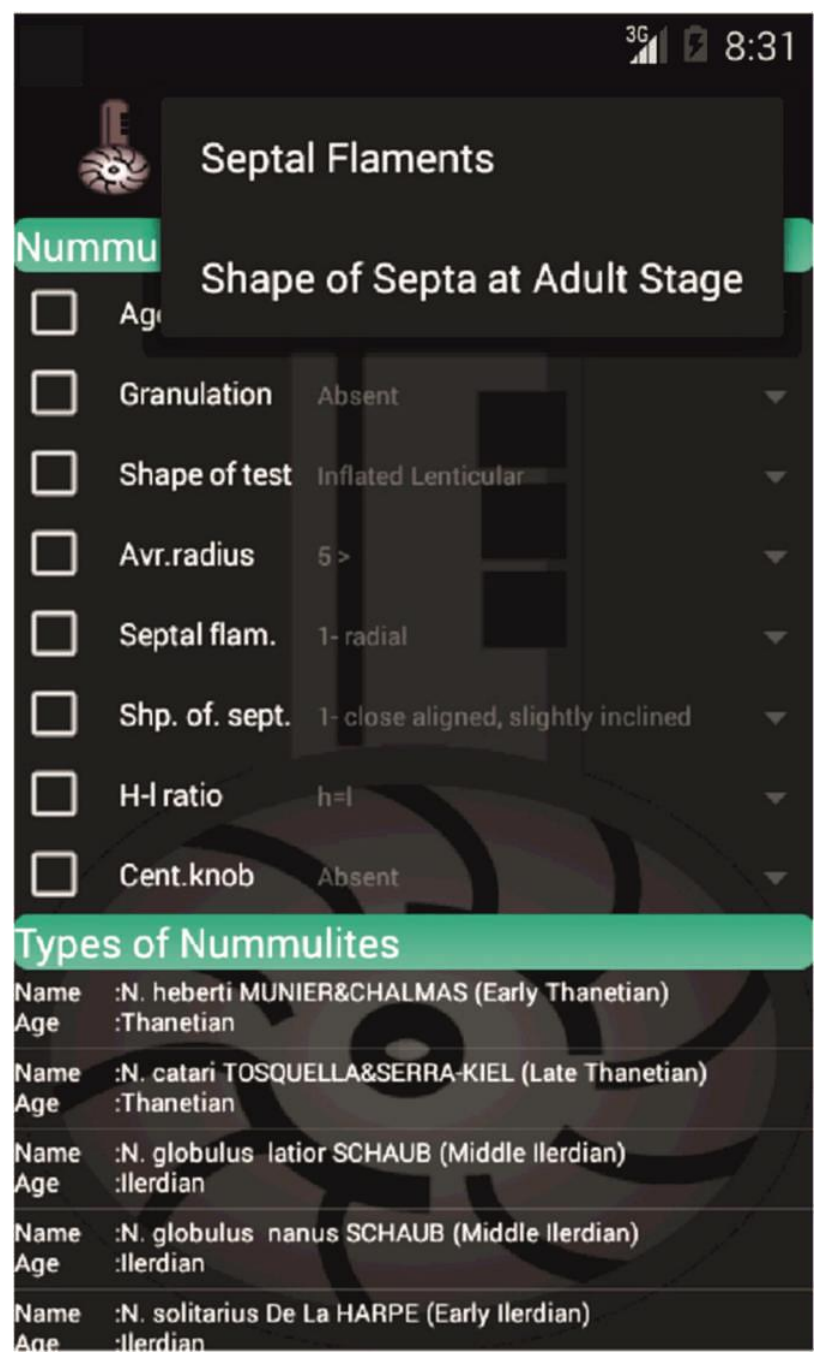

(c)

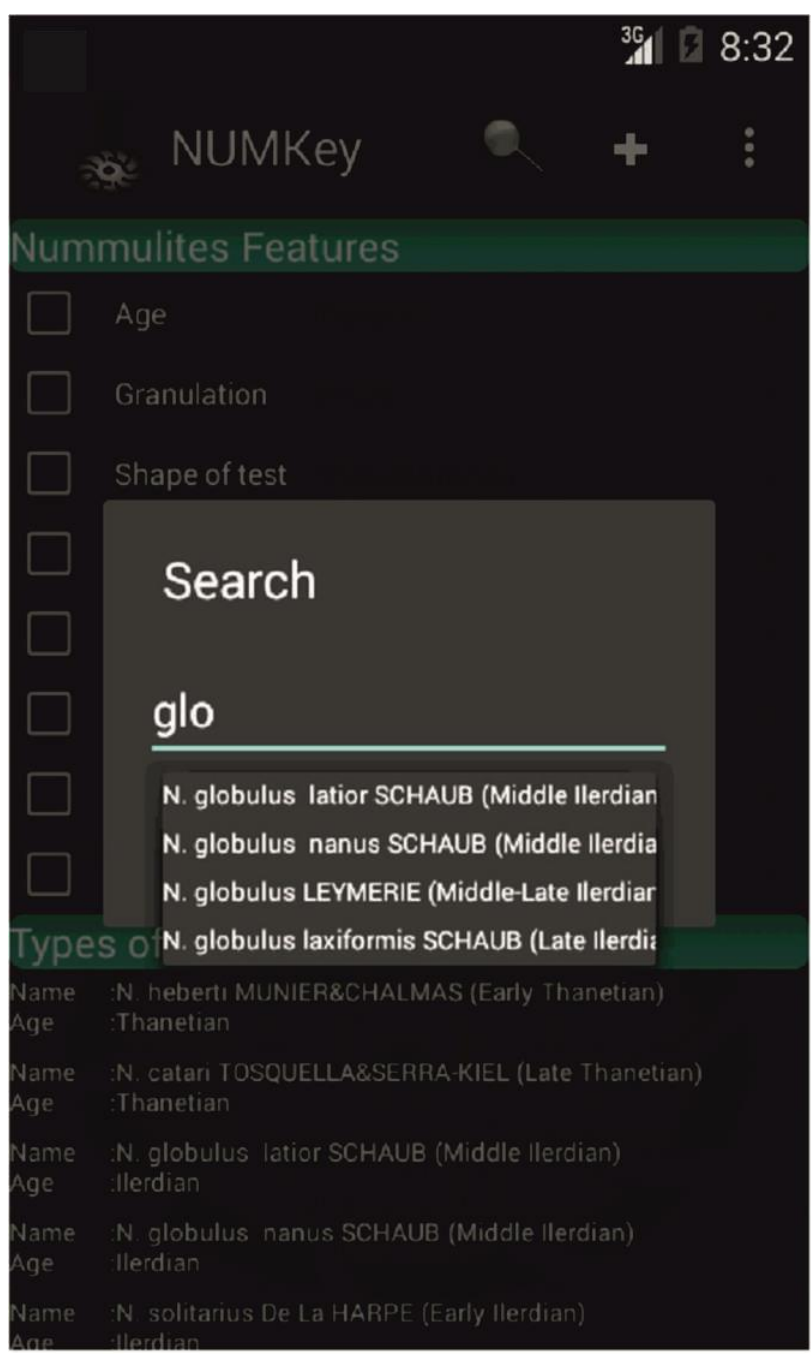

(d)

Figure 7: (c): Selecting "Septal filaments" and "Shape of septa at adult stage" properties on the action bar, (d): The view of the querying table when typing letters in the "Search" textbox.

\section{Testing}

In this section, four species from Çayraz locality (Haymana, Ankara, Turkey), including Nummulites perforatus (de Montford) (Figure 8A), Nummulites burdigalensis cantabricus Schaub (Figure 8B) and Nummulites rotularius Deshayes (Figure $8 \mathrm{C}$ ) are taken into consideration under the scope of testing. All the figures used in Figure 8 were taken from [20] (plate 1, figures 1; plate 2, figures 1, 7) and [21] (plate 3 , figures $8,11,13,15$; plate 5 , figures $21,23-25$ ).

The first example is the specimen of Nummulites perforatus (de Montford) (Figure 8A) from [20]. This beaded species (Figire 8A-2) includes an inflated lenticular test shape (Figure 8A-3) with meandriform septal filaments (Figure 8A-2). The length of the chamber is greater than its height in the adult stage (Figure 8A-1). The shape of septa resembles spaced-flexuous as stated in step 6 in NUMKey. When these data are entered into the program, four species including N. crassus, N. aturicus, $N$. praeaturicus and $N$. perforatus are determined. The first three species belong to Lutetian age. With the knowledge obtained, we only need to look at a few out of 138 species. If we are sure that the studied stratum is Bartonian, only N. perforatus will remain after the query.

The second example is for the comparison of two species at the same locality. $N$. burdigalensis cantabricus Schaub (Figure 8B) and $N$. rotularius Deshayes (Figure $8 \mathrm{C}$ ) are the two Cuisian species in Çayraz locality (Haymana, Ankara) from [21]. At first look, the free specimens of these two species are similar with their medium sized inflated lenticular test shape, radial septal filaments, isometric chambers $(\mathrm{h}=\mathrm{l})$ and absence of central knob (Figure 8B; Figure 8C). As noticed in Figure 8B-5 and Figure 8C-10, the main difference between these two species is beading. When the query is made by entering "granulation = absent", the program gives only two species including $N$. rotularius and $N$. ornatus in Cuisian age (Figure 9a). If we choose the granulation section as "present", the program gives eight species including other $N$. burdigalensis subspecies (Figure 9b). After the query, the exact determination can be done by the help of the size differences between the species and detailed investigation over our specimens. 


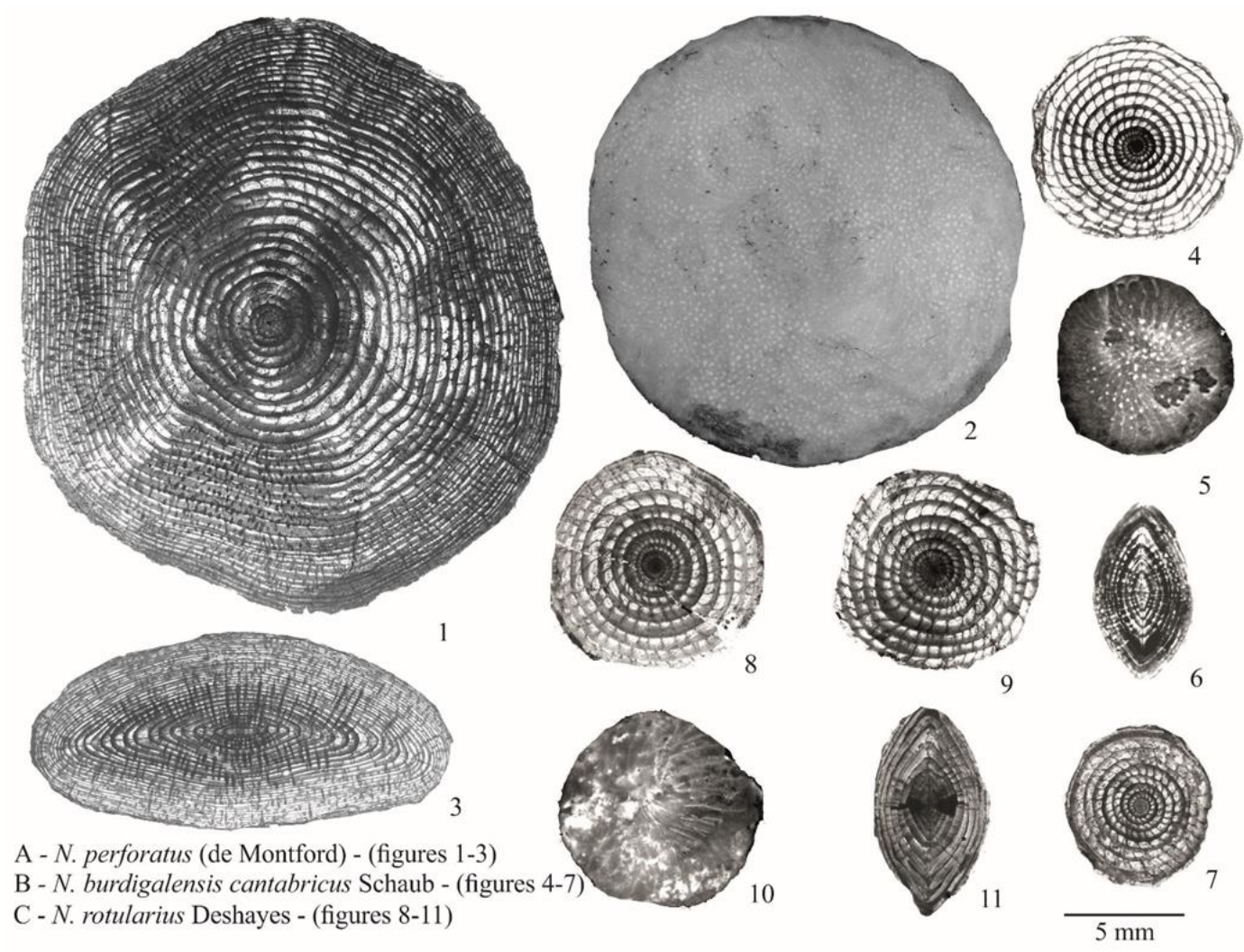

Figure 8: The selected B-forms of some Nummulites species for testing (the samples are arranged from [20]-[21]).
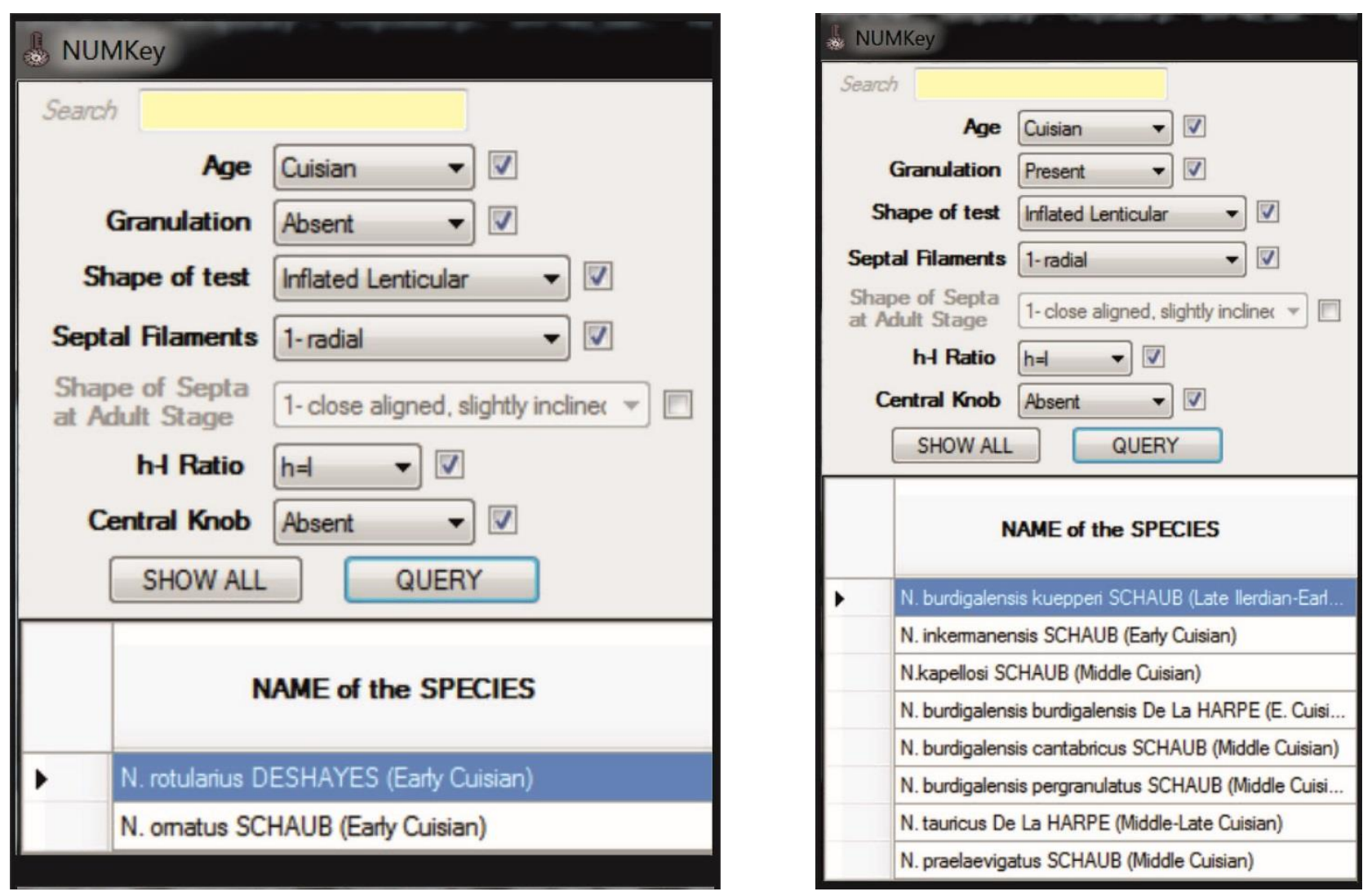

Figure 9(a): The query for Nummulites rotularius, (b): The query for Nummulites burdigalensis cantabricus. 
We think that it is necessary to offer a warning in this section. Though this taxon has been studied since the early times of paleontology, some species do not have a holotype. All data in the NumKEY were taken from previously mentioned authors. It should be appreciated that some observations can vary from person to person. In this case, the users of the program have the chance to modify the source code or the database to adapt the results accordingly.

\section{Conclusions}

The NUMKey is a database program to help for determination of the Nummulites species. This is the first database program to compare the physical features of the fossil species. The major advantage of this program is its functionality for detecting the species based on certain physical properties. By using this program, necessary information can be reached practically and efficiently, instead of by scanning multiple literatures. New species can be added into the database, and since it is an opensource database program, users can make modifications to the source code of the program.

Making a portable version of the program is another important advantage, as it can be easily used anywhere. In the absence of a similar program on this subject, this program can also be used as a preliminary study for making a more comprehensive database in the future.

\section{Acknowledgements}

The authors would like to thank Ercüment Sirel for giving the main idea of the paper and Birkan Alan for her contributions. We are also grateful the 3 anonymous reviewers for their helpful and valuable reviews and also Alissa Goudswaard for revising the language of the manuscript.

\section{References}

[1] Lamarck JB. Systeme des Animaux Sans Vertebres. Paris, France, The Autor, 1801.

[2] Bruguiere JG. Histoire naturelle des Vers, Series: Encyclopedie methodique. Paris, France, Chez Panckoucke, Imprimeur-Libraire, 1792.

[3] Smouth, AH. Lower Tertiary Foraminifera of the Qatar Peninsula-Trustees of British Museum. London, England, Jarrold and Sons LTD, 1954.

[4] Trevisani E, Papazzoni, CA. "Paleoenvironmental control on the morphology of nummulites fabianii (Prever) in the late priabonian parasequences of the moritisa sandstone (Venetian Alps, Northern Italy)". Rivista Italiana di Paleontolojia e Stratigraphia, 102(3), 363-366, 1996.

[5] Papazzoni CA. "Preliminary palaeontological observations on some examples of "nummulite banks": Sedimentary or biological origin?". Rendiconti Online della Società Geologica Italiana, 2, 135-138, 2008.

[6] Serra-Kiel J, Hottinger L, Drobne K, Fernandez C, Jauhri, AK, Less G, Pavlovec R, Pignatti J, Samson JM, Schaub H, Sirel E, Strougo A, Tambareau Y, Tosquella J, Zakrevskaya E. "Larger foraminiferal biostratigraphy of the Tethyan Paleocene and Eocene". Bulletin de la Société Géologique de France, 169(2), 281-299, 1998.
[7] Schaub H. Nummulites et Assilines de la Tethys Paleogene: Taxonomie, Phylogenese et Biostratigraphie. Basel, Switzerland, Museum d'Histoire Naturelle, 1981.

[8] Boussac J. Etudes paleontologiques sur le Nummulitique alpin, Memoires Pour Servir a l'explication de la Carte Geologique Detaillee de la France. Paris, France, Imprimerie Nationale, 1911.

[9] Llueca GF. Los Numulitidos de Espana. Espana, Madrid, Museo Nacional de Ciencias Naturales, 1929.

[10] Roslozsnik P. "Studien über Nummuliten". Geologica Hungarica Series Paleontologica, 2, 1-164. 1929.

[11] Davies LM. "The upper Kirthar beds of north-west India". Quarterly Journal of the Geological Society, 96(2), 199-230, 1940.

[12] Kacharava ZD. "On the Phylogenetic Sequence of the Nummulites fabianii Group". Bulletin of the Georgian National Academy of Sciences, 55, 498-500, 1969.

[13] Blondeau A. Les Nummulites: De l'enseigment a la recherche des sciences de la terre. Paris, France, Libraire Vuibert, 1972.

[14] Löser H. "PaleoTax-a database program for palaeontological data". Computers \& Geosciences, 30(5), 513-521, 2004.

[15] Loeblich ARJr, Tappan H. Sarcodina, chiefly "Thecamoebians" and Foraminiferida. Editor: Moore RC. Treatise on Invertebrate Paleontology, Part C, Kansas, USA, Geological Society of America and University of Kansas Press, 1964.

[16] Loeblich ARJr, Tappan, H. Foraminiferal genera and their classification. New York, USA, Springer Science+Business Media, 1987.

[17] Hottinger L. "Illustrated glossary of terms used in foraminiferal research". Carnets de Géologie/Notebooks on Geologie Memoir, 2006(2), 44-64, 2006.

[18] Sirel E. "Foraminiferal description and biostratigraphy of the Bartonian, Priabonian and Oligocene shallow-water sediments of the southern and eastern Turkey". Revue de Paleobiologie, 22(1), 269-339, 2003.

[19] Microsoft. "Microsoft Download Center". http://www.microsoft.com/enus/download/details.aspx?id=23734 (06.03.2015).

[20] Deveciler A. "The first appearance of the Bartonian benthic foraminifera at the Chayraz Section (north of Haymana, south of Ankara, central Turkey)". Yerbilimleri, 31(3), 191-203, 2010.

[21] Deveciler A. Haymana-Polatlı Havzası Nummulites Lamarck ve Assilina d'Orbigny (Nummulitidae familyası) Türlerinin Tanımlaması ve Bunların Biyostratigrafisi. Doktora Tezi, Ankara Üniversitesi, Ankara, Türkiye, 2014. 